\title{
WORKING WITH DYING PEOPLE: CRISES AND COMPENSATIONS
}

\author{
Robert C. McKay
}

\begin{abstract}
In dying and death situations health providers need to be aware of their approach toward death and their work so that they can sustain both themselves and their patients in offering competent service. Those who work constantly with dying people need to explore (i) their morives in posing such work, (ii) the vocational goals they set themselves, (iii) how they regard their own and their patients' deaths, (iv) what defences they use to protect themselves from the emotional impact of dying and death, and (v) what means they employ in managing stress and burnout. This article discusses these core issues and makes practical suggestions for healsh providers in caring for themselves and dying people.

\section{Opsomming}

Om 'n bevoegde diens aan die pasiënt te lewer in die sterwenssituasie, is dit noadsaaklik dat gesondheidswerkers bewus moet wees van hul eie benadering tot die dood en tot hul werk, om sodoende hulself sowel as hul pasiënte ten beste te aan dien. Gesondheidswerkers wat gereeld met sterwende pasiënte werk, moet hulself ondersoek ten opsigte van: (i) die motivering van hul keuse om hierdie soort werk te doen; (ii) die beroepsdoelstellings war hulle aan hulself stel; (iii) hul persepsie van hul eie dood sowel as die dood van hul pasiënte; (iv) die verdedigingsmeganismes wat hulle gebruik om hulself reen die emosionele impak van die dood te beskerm; ( $v$ ) die metodes wat hulle gebruik om stres en uitbranding te hanteer. Hierdie artikel spreek hierdie kernaspeke aan en maak praktiese voorstelle vir gesondheidswerkers om na hulself sowel as na die sterwende pasiëru om te sien.
\end{abstract}

\section{INTRODUCTION}

\section{$P$ any people death is a remote phenomenon;} only when friends or family members die do they come into contact with the emotional trauma that death brings with it. The defence that death is remote is not available to those who work with the dying. Health professionals face one death after another. Therefore it is important to ask what effect this constant exposure to death has on people working with the dying and how they cope with such a recurring reality (Stedeford, 1984). Overall evidence suggests that the majority of health care workers are prepared inadequately for terminal care issues and concems (Benoliel, 1987). The climate in which health-care practice is leamed tends to emphasize mastery, control and activity but what merits further investigation is the influence of death education and various attitudes about death on health professionals, as well as the identification of death concerns (Bascue, Lawrence \& Sessions, 1977; Moore, 1984). Health-care training should include theoretical materials, clinical data and experiences as well as personal insight into the health-care worker's response to dying and death (Stephenson, 1981).

\section{THE MOTIVES AND GOALS OF THOSE WORKING WITH TIIE DYING}

\section{Motivation}

A complex set of interactional relationships among health professionals working with dying people seems to exist; these include entering characteristics, organizationally-related variables, stress response, ways of coping, and social supports (Garfield and Jenkins, 1981). According to Garfield and Jenkins, the high frequency of reports of personal loss within the past twenty-four months suggests that such losses may play a major role in people's decision to join a group like SHANTI and in their experience after joining. This conclusion seems to be supported by Ingles (in Garfield and Jenkins, 1981) of volunteer motivation in St Christopher's Hospice, London; he reports that bereaved family members often become volunteers to facititate closure on their own personal bereavement. This population may have a greater tolerance for a higher level of stress response than non-volunteers.

Naturally compassion and other such commendable motives draw people to care for the dying in spite of their fear. They learn to overcome that part of their nature that would naturally avoid such dying-and-death encounters. These professionals and volunteers become, in a sense, used to death but they are not hardened in coping with prolonged exposure to dying people.

\section{Goal-setting}

There are two aspects to goal-setting:- what the health professional hopes to achieve with, and for, her patients [treatment goals] and what she expects from herself [personal ideals] (Stedeford, 1984). Satisfaction in work depends on having an appropriate distance between one's ideals and performance. If the former are set too low and thus easily achieved, complacency and boredom may result and when they are about right, these ideals function as a stimulating challenge. People attracted to the work of caring for the dying often have very high ideals which may become sources of unwartanted stress but if goals are pitched too high, this leads to a sense of failure and guilt causing poor morale.

Many heal th professionals enter their respective professions because they are rescuers wanting to save people from distress. Seeing hereself as a rescuer may set the health professional up for the unrealistic goal of rescuing the dying patient. Crowder, Yamamoto, and Simonowitz (1976) maintain that stress increases dramatically as health professionals discover the reality about dying patients. Working with patients who are on an irreversible trajectory towards death is a threat to the health professional's senses of power, mastery and control since she may feel that she can have no impact on the dying person's experience despite all her efforts.

According to Benoliel (1987), there is evidence that due to a combination of personality structure and training experiences, physicians associate dying patients with failure and disappointment. Health professionals realize that patients death and suffering are unavoidable and feel traumatized as they experience the 
reality of death. Death may make health professionals painfully aware of their own losses; it may contribute to their own apprehension regarding their own potential and feared losses; and it may arouse existential anxiety in their personal death awareness (Rando, 1984)

Without adequate processing, health professionals may experience the rescuer expectation as emotional overload since they never succeed in fulfilling their expectations. Mouming responses of medical students and nurses were observed to be associated with loss through identification with a patient's loss of functions and capacities and the giving up of the idealized expectation of the omnipotent helper (Benoliel, 1987). A feeling of helplessness can lead to exhauston and depression (Rando, 1984). Either accepting the reality of death and working through it, or attempting to suppress it, can be stressful, leading to fatigue, over-activity, irritability, and other problems, such as ineffectiveness at work and interference with personal and family life (Stedeford, 1984). The health provider needs rather to accept the inevitability of death and the fact that ultimately it comes to everyone.

Health professionals set themselves up for further disenchantment in believing that death is romantic, that they should like all their patients and that all deaths are peaceful. Staff may work toward achieving peaceful death for the sake of the relatives and themselves, forgetting the there are patients who remain angry right up to the last minute because they are dying (Stedeford, 1984). If staff feel guilty about not liking a client or patient they should realize that they do not choose the patients who come under their care and that some of them are people they would never encounter in the normal course of events because of differing backgrounds or circumstances (Stedeford, 1984).

\section{ISSUES IN WORKING WITH THE DYING}

According to Stedeford (1984) health professionals care for dying patients best when they have allowed themselves to reflect on their own mortality and therefore not to shy away from dying patients. Whelan and Warren (1980) found a significant change in the perceprual reorganization of ideas about, and emotional responses, to death in a treatment group after they explored the meaning of their death.

People who work with the dying need to gain personal insight into their response to dying and death rather than follow rigid stereotyped positions about patients and patient care if they want to foster their own personal growth through attitude and behaviour change. Facing dying and death issues provokes thoughts, concerns and reflections about the meaning of one's own life and they permit one to appraise critically the busyness of life (Lewis, 1982).
Personal growth of this nature requires time and opportunity for reflection (Benoliel, 1987). Professional socialization with dying and death issues means that health professionals need to confront their personal values and their deep-seated beliefs so that they may become more aware of their perceptions about themselves and what their limits are in providing health care (Stephenson, 1981; Stedeford, 1984).Dying and death issues do not have to be totally worked through, but if those who work with the dying do not try to understand them, their anxieties and defences will hamper their work. By addressing them, they may be strengthened by finding values and meanings which make sense to them and give comfort and sustenance as they grapple with life and death on a daily basis. Some of these understandings may come from organized religion or philosophies, or from personal insights.

\section{Facing One's Own Death}

Any contact with someone who is dying inevitably touches people personally and generates situations of personal crisis. As health professionals confront the reality of patients' impending deaths they must confront simultaneously the reality of their own eventual death (Schmale, 1980). Dying is very anxiety-provoking for health professionals in thinking about, planning, and preparing for their own deaths (Cohen, 1983) and the immanence of death may be the most emorionally overwhelming situation that health professionals have to confront (Stedeford, 1984).

Cohen (1983) maintains that those who work with the dying have an ethical responsibility to plan and prepare for their own deaths. According to him, the confrontation with one's dying is the heart of the learning experience in gaining the necessary understanding and insight into the defences people who work with the dying use against the anxiety associated wi th the process of dying and the event of death itself. Dahlberg recognized that his intimate encounter with death "had activated my own fears of death; I was then able to face and work through them with greater equanimity. I don't suppose one ever totally accepts one's own death until just before the end, but it is possible to come to some sort of terms" (Dahlberg, 1980, 370). The process of mouming and grieving for self is a vital issue. The life experiences of health professionals often provide unique opportunities for continued maturation as a health-care worker.

\section{Mourning behaviours}

With the erosion of traditional kinship networks, the disengagement of family members from the dying family member, and the absence of family owing to social mobility or the segregation of the dying person in institutions, health providers find themselves participating in the emotional and social care of the patients. This results in heal th professionals taking emotional risks and forming bonds that will demand a grief response when that bond is terminated by death (Cohen and Wellisch, 1978). In caring for dying individuals care-givers are subject to experiences that will require a grief response of their own as anyone who loses something or someone in whom he has invested himself emotionally, needs to grieve (Schwartz \& Karasu, 1977).

\section{DEFENCES USED IN TERMINAL CARE}

Defence mechanisms are double -edged tools of everyday life; correctly used and understood. defences help people to adapt and give better care, but used excessively or negatively when acceptance and working through would be more creative, they are disadvantageous (Stedeford, 1984). I has been reported that coping strategies used by nurses on high-death wards are designed to control emotional attachment to patients, to minimize negligence concerns, a to foster acceptable performance; in intensive care, a common strategy is to mask death by an emphasis on recovery, but apparently, this strategy is not effective on cancer wards which are characterized by many interactional problems. Recent research on cancer wards indicates that staff cope with problem situations and their own emotional reactions by making referrals to a consulting psychologist and by using scapegoating as a method of relieving tension on the ward.(Benoliel 1987).

\section{Denial, Withdrawal and Isolation}

The confrontation of death in non-terminally ill people evokes reactions similar to the stages of denial, anger, bargaining, depression and acceptance (Kubler-Ross, 1969) but these reactions are flucruating in nature rather than a static progression from one stage to another. The individual's capacity to overcome der and to come to grips with death seems to elicr. emotions and attitudes showing little adherence 10 an ordered, sequential movement (Whelan and Warren, 1980). A considerable amount of energy is used in denying the inevitability of death when working closely with dying people. In denial, people are unable to express emotions related to death and this lack of affect frequently reaches the level of complete absence of all feeling through retreat into a detached, emotionally unavailable state. According to Halpert (1982), when this level of denial is reached the health professional's interest in the patient and her ability to maintain neutrality, objectivity and empathy are significantly impaired. Once denial is overcome people are able to deal with the repressed emotions elicited by caring for the dying.

Ineffective means of managing and coping with the anxiety caused when a patient is dying may result in withdrawal from the patient and her family, despite the fact that observational studies of nurses have shown that they spend more time with dying patients than with the 
nondying (Benoliel, 1987; Rando, 1984). Apparently these nurses display verbal and nonverbal avoidance in spite of the actual greater amount of time spent with dying patients. Health providers may use social distance in their interactions with dying patients to counteract professional loss associated with negation of professional competence, negligent behaviour, loss of peer respect, loss of professional deportment, or loss of a significant patient (Rando, 1984).

Goldie (1981) observes that when it becomes evident that a patient is going to die and there are no physical manoeuvres to prevent this, staff members frequently look the other way; ward rounds may miss the patient or a transfer to special units is arranged in order to avoid the pain of caring until death occurs, or nurses maintain a brusque cheerfulness in order to keep a happy atmosphere in the ward. Social workers often concentrate exclusively on solving pracrical problems and clergy offer only formal $p$ ers or cheerful news of the parish community. Studies of personnel in nursing homes indicate that by avoiding discussions of death with their patients and by staying busy with their physical care and other tasks (that is, by controlling their work environment), they are able to manage their latent anxieties (Benoliel, 1987). The direct cause of these and similar behaviours may be ignorance and thoughtlessness, but the unconscious motivation is one of defence, to spare the health provider from anxiery (Boots, 1971). Everley $(1979,8)$ has pleaded: "Let us not wall the dying into silence by avoiding their timid, often symbolic advances. Let us not leave them alone, let us not anticipate, by our avoidance, the death which is soon going to separate them from the ones they love".

\section{Intellectualization}

$\mathrm{g}$ initial confrontation with dying and decur heal th providers are very intellectualized in their focus on professional knowledge and factual (even philosophical) issues. "It may become a matter of pride to those responsible for his treatment that he shall die with his blood chemistry as near normal as possible, for whatever other civil right may be denied him, these last rights ensure that he can die with his serum electrolytes in balance" (Simpson, 1986, 3). Often conversations with patients are impersonal; doctors manage to avoid their own pain by rationalizing (patients do not really want to know the fact of their condition), intellectualizing (talking about theoretical matters like survival times or percentage cure rates), telling the truth bluntly and disappearing quickly, or delegating the job to someone else (Rando, 1984; Stedeford, 1984).

\section{Identification}

Putting oneself imaginatively in another's place increases sensitivity to their needs and can help in deciding what would be best for them, but it can also lead to serious mistakes if one does not acknowledge that total identification with another is impossible. Interviews with nurses on care of the dying showed their stresses related to identification with the patient, distressing types of dying, patients' changes in physical appearance, lack of clear policies governing action to take, and medical decisions to prolong life when the patient obviously was not going to survive (Benoliel, 1987). Identification for a health provider has gone too far when he begins to think and feel like the person for whom he is caring; the health provider becomes over-burdened with emotion which does not belong to him and thus becomes less effective as a helper (Stedeford, 1984). It can be helpful to affirm to oneself that one's patients are not one's relatives.

\section{Generalization}

Generalization (applying something that is learned in one setting to a different context) is detrimental to health providers when it is applied outside appropriate limits. Some doctors, nurses and hospice staff become unduly anxious when they themselves are ill. Hospice staff work in an environment where ultimately atmost every patient's physical condition worsens, and where almost all of them die; their experience teaches them that pain is usually caused by cancer and cancer leads to death. When they are in pain or a relative discovers a lump, health providers experience an unreasonable level of anxiety and lose sight of things they know quite well - cancer is only one of many causes for pain, that not all lumps are malignant, and not everyone who has cancer will necessarily die. The anxiery of health providers can be reduced quire effectively by gaining insight into the way generalization has occurred from their work setting to their personal life (Stedeford, 1984).

\section{Displacement}

Anger is frequently used as a defence against death and severe loss of control; it is seen as a way of controlling the environment (Van Dyke Platt, 1977). Displacement is disturbing when a patient's anger about his impending death, delayed diagnosis, or the general unfairness of fate is directed at staff who are accused of negligence, inattentiveness and lack of care. Scapegoaring may occur if one person or event is regarded as the cause of all the trouble, but the release of emotion is at the expense of another individual and this hinders any constructive thinking about how to deal with present and real issues being faced. Patients use projection when they cannot tolerate the knowledge that they are dying and project blame onto others, either symbolically by saying things like 'You're stealing my money', or more directly by statements such as 'Your injections are killing me'. Should a patient die a short time after an injection such blame may echo in the health provider's ear for a long time and lead to distress. If health providers, especially nurses, begin to doubt their efficiency and competence in administering medication, then senior staff members need to support inexperienced staff especially in the administration of drugs as this situation may cause undue stress (Stedeford, 1984).

From the family and staff vantage point, displaced anger and hostility is difficult to deal with as the anger is aimed in many directions nurses, doctors, hospital, family, friends, God. Sometimes family, care-givers and medical statf withdraw from the dying person because of his outbursts, a situation which further increases the person's loneliness and isolation (Hinton, 1967; Reilly, 1978; Bugen, 1979; Stedeford, 1984; Poss, 1981). By shifting their feelings on to others, those who are dying are able to remain relatively calm and in this sense displacement is adaptive. It is important that the dying person's anger toward family, friends and doctor be verbalized, but the health provider must be careful not to add to the burden of guilt the dying person already carries (Schoenberg and Senescu, 1970). If family, friends and medical staff are able to deal with the dying person's reactions without counter-hostility, then usually hostility abates. The important task of the family is to be there with the dying person What those who are facing death share may well be anger, frustration, pain, guilt, blame, denial but the willingness of all concerned to listen and respond to the issues and questions which immediately concern the dying person, is a way of enabling her to deal with the crisis of meaning in the face of death (Popa and Hanganu, 1979). As Saunders $(1969,62)$ has stated succinctly: "You must be ready to listen; you must be ready to be silent; and you must just be committed".

\section{Emotional Arrival}

'Emotional arrival' in working with dying patients implies a sense of freedom from the debilitating effects of the fear, denial, social isolation and withdrawal, and identification with patients' symptoms (Stedeford, 1984). That is, the health providers are no longer preoccupied with their own dying and death, they no longer feel guilty about their own good health and they are not incapacitated by depression. This emotional state, however, does not mean that health providers no longer experience pain when working with dying patients; their sensitivities are sharpened rather than dulled, their emotional responses are appropriate, they have the sensitivity to grieve and the resilience to recover (Rando, 1984).

\section{PROFESSIONAL BURNOUT/ STRESS}

\section{Stress}

Stress is the non-specific response of the body to any demand made upon it (Garfield and Jenkins, 1981). Working with dying people is draining and exhausting since not only does one spend much time with the dying, one is also dealing with vital questions and powerful emotions (McKay, 1990). It is difficult to remain emotionally-aloof, detached and objective in such situations. When caring for 
the dying, enquiries about life touch upon one's own questions about life and death. Overall responses to stress by health professionals include malaise, irritability, sleep disturbances, use of drugs or alcohol, depression, guilt over taking time off, inability to detach from work, and marital problems. Specific behavioural manifestations of staff stress involves staff conflict, displaced hostility, withdrawal from patients, exhaustion, and interference with personal lives (Stedeford, 1984). It is essential that health providers leam to recognize stress and understand its causes so that they may care for one another in such a way to foster personal and professional growth. Knowledge of the stressors and the coping experience of persons counselling the dying makes a contribution to better services to patients and lessens distress for health professionals.

Studies of stressors in critical care nursing have consistently identified factors such as continued exposure to death, interpersonal conflicts and differences of opinion, communication problems among staff members, workload and management problems (Stedeford, 1984). Interviews with nurses on care of the dying showed that their stresses are related to identification with the patient, types of dying, patients' changes in physical appearance, lack of clear policies governing action to take, and medical decisions to prolong life when the patient obviously was not going to survive (Benoliel, 1987). The sources of stress identified by physicians have included identification with the patient, living up to unrealistic expectations, handling multiple roles, and the politios of the system. Every health provider needs to identify her specific stresses in working with the dying so that she can anticipate and counteract them.

\section{Burnout}

Burnout is a syndrome of emotional, physical and occupational exhaustion and cynicism occurring often among people who work with people and spend a considerable amount of time in close encounters with others under conditions of chronic tension and stress. In preventing burnout it is necessary to be aware of one's feelings and to be honest about them. Terminal health providers need to admit and express their feelings and needs which may include their anger or disgust, requests for assistance when they need it without feeling guilty, or relinquishing concern for patients when they are not at work. It is also important for those who work with dying people to have varied and compelling interests quite separate from their professional lives.

On a more practical level health providers need to real ize that they deserve and need breaks from the stressful parts of their work by arranging for free time during the day or days off for relaxation and by varying time between stressful and less stressful patients either on a daily basis or over longer periods. Holidays are important and must be given a high priority.

\section{Resources of Work Satisfaction}

Sources of satisfaction for health providers comes from direct patient care, the acquisition of new knowledge, opportunities for close communication with families, collegiality with other providers and a feeling of usefulness (Benoliel, 1987). It is important thus to provide constant reinforcement for those who most frequently deal with the trauma of dying and death.Individual counselling by pastoral carers, and other supportive personnel has been the primary response to this need thus far (Marie, 1978). Raphael in Rando, (1984) advocates that the health professionals also should become involved in continuing support systems such as peer support groups, and case discussion meetings. I have found it very necessary to have my own support system with whom to process thoughts and feelings about the subject of dying and death, and my own responses to the dying people with whom I work.

\section{CONCLUSION}

Most people are only intimately concerned with death a few times in their lives, but for health providers in a terminal care setting dying is an everyday reality which requires a great deal from them. Dying and death, therefore, is too important and too sensitive an area not to be a part of formal health-care training programmes. Through the personal and intimate experience of working with, and relating to, a dying person, health providers leam about life's basic forces such as living, dying, growing and changing (Curran and Kobos, 1980). But health providers need also to be gentle with themselves!

\section{BIBLIOGRAPIYY}

BASCUE, L.O., LAWRENCE, R.E. \& SESSIONS, J.A. Counselor Experiences with client Death Concerns. Rehabilitation Counselling Bulletin, 21 (1), 36-38.

BENOLIEL, J.Q.(1987). Health Care Providers And Dying Patients: Critical Issues In Terminal Care. Omega, 18 (4),341-357.

BOOTS, D.D. (1971). Helping the Cancer Patient: The Ministerand the social Worker. Pastoral Psychology, 22, 35-40.

BUGEN L.A. (1979). Death and Dying: Theory-Researth-Practice. Dubaque. lowa: Wm. Brown Publishing Co.

COHEN, J. (1983). Psychotherapists Preparing For Death. American Journal of Psychotherapy, 37(2), 222-226.

COHEN, M.M. AND WELLISCH, D.K. (1978). Living in Limbo: Psychosocial Intervention in Families with a Cancer Patient. American Journal of Psychorherapy, 32 (4), 561-571.

CROWDER, J.E., YAMAMOTO, M.D. \& SIMONOWITZ, J. (1976). Training Registered Nurses as Bereavement Counselors in an Occupational Health
Service. Hospital and Community Psychiarry, 27 (12), 851-852.

CURRAN, M.C. AND KOBOS, J.C. (1980). Therapeutic Engagement With a Dying Person: Stimulus For Therapist Training and Growth. Psychorherapy: Theory, Research and Practice, 17 (3), 343-351.

DAHLBERG, C.C. (1980). Perspectives on Death, Dying, and Illness while Working with Patients. Journal of the American Academy of Psychoanalysis, (8), 369-380.

EVERLEY L. (1979). In the Face of Death: New York: Seabury Press.

GARFIELD, C.A. \& JENKINS, GJ. (1981) Stress and Coping of Volunteers Counseling the Dying and Bereaved. Omega (12) 1, 1-13.

GOLDIE, L. (1981). The Problems Arising with Psychotherapy in the Presence of Serious Illness and Death. Projective Psycholo $26(2), 21-23$.

HALPERT, E. (1982). When The Analyst is Chronically III or Dying. Psychoanalytic Quarterly, $5 l$ (3), 372-389.

HINTON, J. (1967). Dying. Harmondsworth and Baltimore: Pelican Books.

KUBLER-ROSS, E. (1969). On Death and Dying. New York: Macmillan Publishing Company.

KUBLER-ROSS, E. (1974). Dying as a Human-Psychological Event. In The Experience of Dying, Greinacher, N. and Muller, A. (Eds), 48-53. New York: Herder and Herder.

KUBLER-ROSS, E. (1981). Living with Death and Dying. New York: Macmillan Publishing Company.

LEWIS, J.M. (1982). Dying with Frier Implications for the Psychotherapist. American Journal of Psychiary, 139 (3), 261-266.

MARIE, H. (1978). Reorienting Staff Attitudes Toward the Dying. Hospital Progress, 59 , 74-76.

MOORE, K. (1984). Training Social Workers to Work with the Terminally III. Health and Social Work, 9(4), 268-273.

POPA, A. AND HANGANU, E. (1979). The Faces of Death. Journal of Medical Ethics, 5, 71-72.

POSS, S. (1981). Towards Death with Digniry. London: George Allen and Unwin Lid.

RANDO, T.A. (1984). Grief, Dying, and Death. Illinois: Research Press Company.

REILLY, D.M. (1978). Death Propensity, Dying, and Bereavement: A Family Systems Perspective. Family Therapy, 5 (1), 35-53. 
SAUNDERS, C. (1969). The Moment of Truth Care of the Dying Person. In Death and Dying: Current Issues in the Treatment of the Dying Person, Pearson, L. (Ed), 49-78. Yew York: University Press Book

SCHMALE, A.H. (1980). The Dying Patient in In Psychotherapeutic Interventions in Life-Threatening Illness, Freyberger, $\mathrm{H}$. (Ed), 99-109. Basel: Tanner and Bosshardt AG.

SCHWARTZ, A.M. AND KARASU, T.B. (1977). Psychotherapy with the Dying Patient. American Journal of Psychotherapy, 31 (1), 19-35.
SCHOENBERG, B. AND SENESCU, R.A (1970). The Patient's Reaction to Fatal Illness. In Loss and Grief: Psychological Management in Medical Practice, Schoenberg, B., Carr, A.C., Perez, D. and Kutscher, A.H. (Ed), 221-237. New York: Columbia University Press.

SIMPSON, M. (1986). The Theology of Death and Eternal Life. Notre Dame, Indiana: Fides Publishers, Inc.

STEDEFORD, A. (1984). Psychotherapy of the Dying Patient. British Journal of Psychiarry, 135, 7-14.
STEPHENSON, J.S. (1981). The Family Therapist and Death: A Profile. Family Relations, $30459-462$.

VAN DYKE PLATT, N. (1977). What Will Happen to the Flowers When Winter Comes? Journal of Religion and Health, 16, 326-332.

WHELAN, W.M. AND WARREN, W.M (1980). A Death Awareness Workshop: Theory, Application and Results. Omega, 11 (1), 61-71

Robert C. McKay

Department of Psychology, UNISA 